\title{
Sea urchin Diadema africanum mass mortality in the subtropical eastern Atlantic: role of waterborne bacteria in a warming ocean
}

\author{
S. Clemente ${ }^{1, *}$, J. Lorenzo-Morales ${ }^{2}$, J. C. Mendoza ${ }^{1}$, C. López $^{1}$, C. Sangil ${ }^{3}$, F. Alves ${ }^{4}$, \\ M. Kaufmann ${ }^{4,5,6}$, J. C. Hernández ${ }^{1}$ \\ ${ }^{1}$ Biodiversidad, Ecología Marina y Conservación, Departamento de Biología Animal (Ciencias Marinas), \\ Facultad de Biología, Universidad de La Laguna, Avda. Astrofísico Francisco Sánchez s/n, 38206 La Laguna, Tenerife, \\ Canary Islands, Spain \\ ${ }^{2}$ University Institute of Tropical Diseases and Public Health of the Canary Islands, Universidad de La Laguna, \\ Avda. Astrofísico Francisco Sánchez s/n, 38203 La Laguna, Tenerife, Canary Islands, Spain \\ ${ }^{3}$ Botánica Marina, Departamento de Biología Vegetal, Universidad de La Laguna, 38071 La Laguna, Tenerife, Canary Islands, Spain \\ ${ }^{4}$ CIIMAR-Madeira (Interdisciplinary Centre of Marine and Environmental Research of Madeira), \\ Edifício Madeira Tecnopolo, Caminho da Penteada, 9020-105 Funchal, Madeira, Portugal \\ ${ }^{5}$ University of Madeira, Centre of Life Sciences, Marine Biology Station of Funchal, 9000-107 Funchal, Madeira, Portugal \\ ${ }^{6}$ CIIMAR/CIMAR (Interdisciplinary Centre of Marine and Environmental Research), University of Porto, Rua dos Bragas 289, \\ 4050-123 Porto, Portugal
}

\begin{abstract}
A widespread mass mortality event of the sea urchin Diadema africanum was detected in the subtropical eastern Atlantic, extending from Madeira to the Canary Islands, covering a straightline distance of $>400 \mathrm{~km}$. This is the first diseaserelated die-off of a diadematid documented in the eastern Atlantic Ocean. Diseased individuals showed deterioration of the epidermis and water-vascular system, resulting in epidermal necrosis and release of spines. Despite some spatial heterogeneity in disease incidence at the study sites, there was a $65 \%$ overall reduction in urchin abundance after the mortality event compared to numbers pre-mortality. However, the reduction in urchin numbers did not compromise the species' reproductive success; the settlement peak following the mortality event was of a similar magnitude to that in prior years. Bacterial isolation and culture techniques, and subsequent laboratory infection experiments, strongly suggested that Vibrio alginolyticus was involved in the disease. We hypothesize that the mass mortality event developed due to anomalously high seawater temperatures recorded in the 2 studied archipelagos and that warmer temperatures enabled infection of $D$. africanum by waterborne pathogenic bacteria. Fluctuations in urchin populations are key in determining the structure and functioning of benthic ecosystems: under the current seawater warming scenario, disease may result in more frequent phase shifts, aiding the persistence of macroalgae.
\end{abstract}

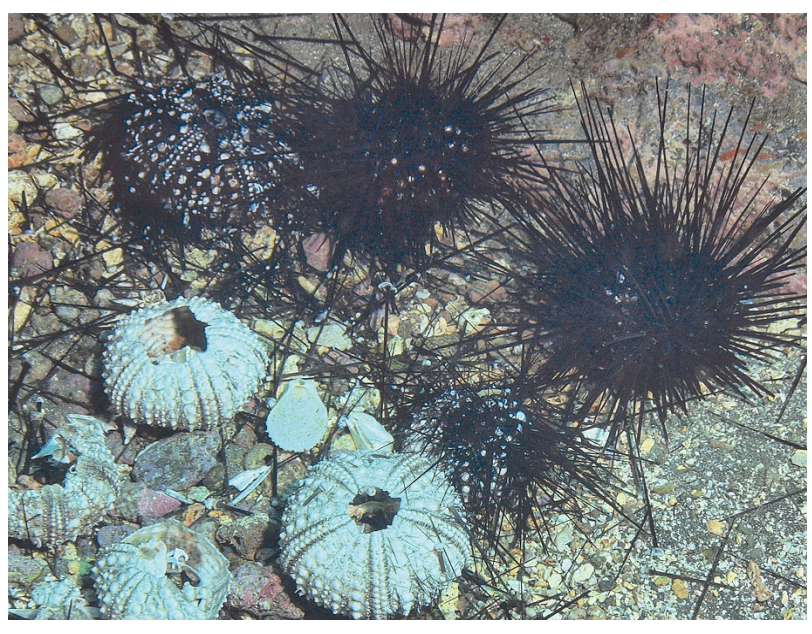

Diadema africanum displaying symptoms of disease and accumulations of dead individuals recorded during the mortality event in the Canary Islands.

Image: Julián Rodríguez Medina

KEY WORDS: Echinoids - Diadematid - Disease · Widespread die-off · Vibrio · Infection experiments · Canary Islands · Madeira

\section{Resale or republication not permitted without} written consent of the publisher 


\section{INTRODUCTION}

In recent decades, mass mortality events resulting from disease have been widely described in the marine environment (e.g. Goreau et al. 1998, HoeghGuldberg 1999, Porter et al. 2001) and the prevalence or severity of these disease outbreaks in marine organisms appears to be increasing (Epstein 1996, Harvell et al. 1999, Hayes et al. 2001, Lafferty et al. 2004). The increase in disease frequency has been linked with a variety of factors that influence the introduction and propagation of pathogens. Many of the identified causes are climate related, such as ocean warming and the incidence of storms (Scheibling \& Hennigar 1997, Harvell et al. 2002, Scheibling et al. 2010, Feehan et al. 2012, Hendler 2013). Anthropogenic pressures may also influence the outbreak of disease, with factors including pollution, harvesting, the introduction of foreign species, or the modification of coastal habitats (Harvell et al. 1999, Lafferty et al. 2004, Hendler 2013, Ebert 2013). Elevated sea-surface temperatures (SST) are commonly associated with reports of marine disease and mass mortalities (Epstein 1996, Harvell et al. 1999). However, establishing cause-effect relationships is extremely complicated given the number of different interacting factors that could be involved (Harvell et al. 1999). Different pathogens may also display different responses to environmental change (Lafferty et al. 2004), with contrasting outcomes for disease development.

Episodes of extensive mortality resulting from disease have been observed in a wide array of marine taxa (Lafferty et al. 2004, Ward \& Lafferty 2004), many of them driving community state shifts (Harvell et al. 1999). The effects are most significant when mortality affects species playing key roles in the ecosystem, such as key producers, key herbivores, or keystone predators. Modifications to community structure and the food web take place when the population of a key species is depleted as a direct consequence of disease progress (Lessios 1988, Scheibling et al. 2013). Many echinoid species can be described as key herbivores, controlling algal production and diversity and hence community state. One of the most notable examples of a sea urchin mass mortality episode was that of Diadema antillarum in the Caribbean (western Atlantic) in the 1980s caused by an unidentified pathogen (Lessios 1988 , 1995). After the abundances of $D$. antillarum were widely decimated in the Caribbean, extensive proliferation of macroalgae occurred. The subsequent dominance of macroalgal stands throughout the region then led to a decrease in coral cover (Lessios 1988, Levitan 1988, Edmunds \& Carpenter 2001). Similarly, in recent decades the sea urchin Strongylocentrotus droebachiensis has suffered recurrent amoeba-induced mass mortalities off the North Atlantic coast of Nova Scotia. In this location, the mortality events were associated with increases in SST and an increase in the incidence of tropical storms (Scheibling \& Hennigar 1997, Scheibling et al. 2010, Feehan et al. 2012). Increased frequencies of diseased sea urchins have also reported in temperate regions during blooms of tropical dinoflagellates of the genus Ostreopsis (Shears \& Ross 2009, and references therein); however, the mechanisms involved largely remain unknown.

Benthic communities in the eastern Atlantic Archipelagos, including Madeira and the Canary Islands, similar to other temperate and subtropical regions, are often characterized by 1 of 2 alternative community states: productive macroalgal beds or barren grounds dominated by sea urchins and encrusting coralline algae (Hernández et al. 2008a). The sea urchin Diadema africanum (Rodríguez et al. 2013) is widely distributed throughout these archipelagos and facilitates the transition from macroalgal beds to urchin-grazed barren grounds due to its intense grazing activity (Alves et al. 2001, Hernández et al. 2008b). To the best of our knowledge, no mortality events of $D$. africanum had been recorded prior to this study in the eastern Atlantic Ocean, and high abundances of the species have persisted for decades in the archipelagos (e.g. Madeira, Alves et al. 2001; the Canarian Archipelago, Hernández et al. 2008b). Only 1 episode of disease causing mass mortality is known for echinoids in this region; it specifically affected intertidal populations of the species Paracentrotus lividus and was related to high SST coupled with extremely low tides (Girard et al. 2012).

For the first time we report here on a mortality event of the sea urchin Diadema africanum in subtropical eastern Atlantic Ocean waters. In October 2009 populations of the sea urchin began to die off around the southeast coastline of Madeira Island; by the end of March 2010 the mortality event had reached some spots of the Canary Islands (Gran Canaria Island, F. Tuya, Universidad de Las Palmas de Gran Canaria, pers. comm.), and by April 2010 it had spread to many areas throughout the archipelagos (Fig. 1).

Disease is an important natural mechanism known to cause mass mortalities of key herbivore sea urchins (Feehan et al. 2012). The comprehensive study of this phenomenon aids our understanding of mechanisms that mediate transitions between alternate 


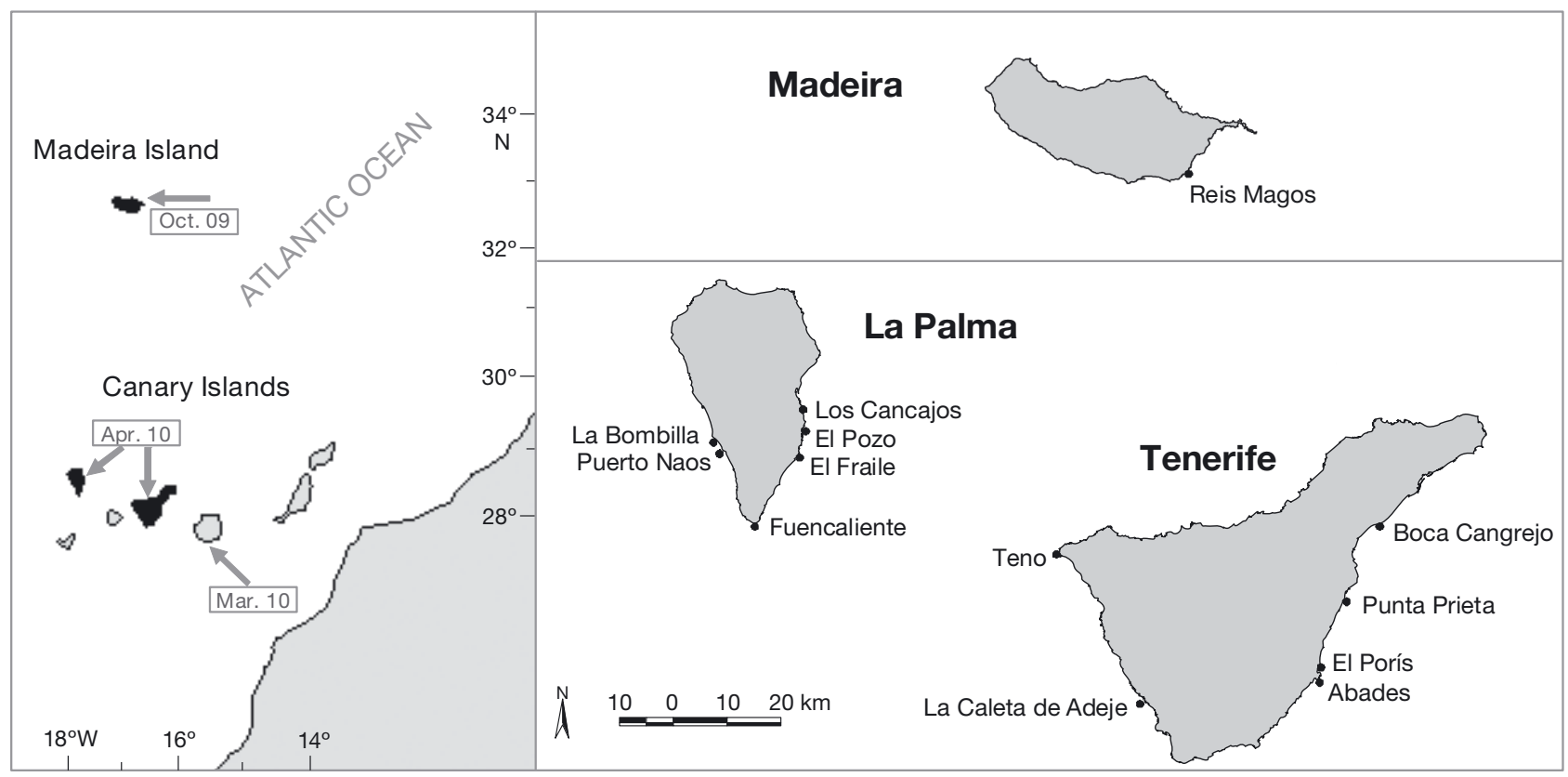

Fig. 1. Study sites around Madeira and the Canary Islands (La Palma and Tenerife). Spread of the mortality event is shown by grey arrows labelled with the timing of observed mortality (month and year)

ecosystem states. We specifically aimed to assess the ecological effects of the reported $D$. africanum die-off throughout the eastern Atlantic archipelagos, and to provide insight into the causative agents of this event. To measure the impact of the mortality event on natural populations of the sea urchin, we recorded abundances and post-disease settlement rates of the echinoid at sites where pre-mortality data were available. Finally, to understand the etiology of sea urchin disease, we cultured and identified internal pathogens and conducted subsequent infection experiments with the isolated pathogen in the laboratory.

\section{MATERIALS AND METHODS}

\section{Study sites: sea urchin populations and SST}

Populations of the sea urchin Diadema africanum were monitored at Madeira Island during November 2009, and at 2 of the Canary Islands (Tenerife and La Palma) from March to May 2010 (Fig. 1). One site (Reis Magos) was studied on the south-eastern coast of Madeira, and 6 sites were monitored around each of the studied islands in the Canaries (Fig. 1).

Historical SST data for the period of the disease outbreak, both for Madeira and the Canary Islands, were obtained from the National Centre for Environ- mental Prediction/National Centre for Atmospheric Research (NCEP/NCAR) reanalysis data for each region (Kalnay et al. 1996).

\section{Abundances of D. africanum}

Different sampling techniques were used at the Madeira site compared with the sites around the Canary Islands, to maintain a consistent methodology that allowed comparisons with existing (pre-mortality event) data for each region. Populations of $D$. africanum were surveyed at rocky shores off Madeira Island using eighteen $1 \mathrm{~m}^{2}$ quadrats (Alves et al. 2001) deployed randomly at 5 to $15 \mathrm{~m}$ depth, twice during the mortality event (3 and 24 November 2009). Around the Canary Islands echinoids were sampled in eight $10 \times 2 \mathrm{~m}$ transect lines laid randomly over the rocky substrate parallel to the coastline (Hernández et al. 2008b), at depths of 5 to $15 \mathrm{~m}$ during the mortality event (9 April to 20 May 2010 at Tenerife; 15 April to 15 May 2010 at La Palma). The numbers of living echinoids were recorded for each sampling replicate.

\section{Settlement of D. africanum}

We studied settlement rates of $D$. africanum during the known annual settlement peak from August to October (Hernández et al. 2006), which took place 
5 to 7 mo after the sea urchin mortality event. We defined settlement as the monthly appearance of newly settled sea urchin individuals on artificial collectors. Each artificial collector consisted of 100 moulded $3.9 \mathrm{~cm}$ diameter plastic balls (biofilters) placed into a mesh bag (Hernández et al. 2006), which provided a large surface area favourable for larval settlement (Harrold et al. 1991, Hernández et al. 2010). These collectors were used at 2 urchinbarren sites off Tenerife, Canary Islands (Abades and Boca Cangrejo) (Fig. 1), where long-term settlement data were available for the sea urchin before the occurrence of the mortality event (2003 to 2008) (data taken from Hernández et al. 2006). At each sampling site, 3 replicate samplers were deployed at 6 to $10 \mathrm{~m}$ depth (placed $1 \mathrm{~m}$ above the seafloor). Samplers were replaced every month using the method described by Hernández et al. (2006), and the number of newly settled $D$. africanum larvae was determined for each month, using a dissecting microscope.

\section{Identification of pathogens}

We investigated the cause of disease by culturing and identifying internal pathogens of sea urchins. Samples of both healthy and diseased echinoids were collected from 2 sites in the Canary Islands where sea urchins showed signs of disease and high mortality rates (21 individuals from Abades and 34 individuals from Punta Prieta) (Fig. 1). Individuals were placed in insulated containers, transferred to the laboratory within $2 \mathrm{~h}$, and then maintained in $250 \mathrm{l}$ tanks supplied with running filtered and UV-sterilized seawater at ambient temperature for a short time (about $1 \mathrm{~h}$ ) before the next stage of processing.

\section{Isolation and bacterial culture}

Fifty-five sea urchins (41 healthy individuals, 15 collected in Abades and 26 in Punta Prieta; and 14 diseased individuals, 6 from Abades and 8 from Punta Prieta) (Fig. 1) were processed in the laboratory. Screening of individuals was restricted to the coelomic fluid, and all samples were taken after the seawater had been drained away from the mouth area and spiny surface. An $18 \mathrm{G} \times 1.5^{\prime}$ needle was inserted through the peristomal membrane at an angle that avoided contact with the lantern area, and a small volume of coelomic fluid (up to $5 \mathrm{ml}$ for large specimens) was withdrawn into a sterile disposable syringe. Three to 4 drops of coelomic fluid were placed on the surface of specific media for the isolation of Vibrio spp. (TCBS agar, Merck), Aeromonas spp. (Aeromonas agar, Oxoid) and Pseudomonas spp. (Cetrimide agar, Scharlab). Inoculated plates $\left(3\right.$ ind. $\left.^{-1}\right)$ were incubated for $48 \mathrm{~h}$ at $37^{\circ} \mathrm{C}$, which is an optimal temperature for bacterial growth (Khouadja et al. 2013), and were checked daily for the presence of bacterial growth.

\section{DNA extraction and PCR}

Bacterial isolates were obtained by aseptically inoculating $50 \mu \mathrm{l}$ Luria-Bertani broth with colonies taken from plated media. The cultures were then incubated at $95^{\circ} \mathrm{C}$ for 10 min to lyse the cells, then at $4^{\circ} \mathrm{C}$ for at least $10 \mathrm{~min}$ to prevent DNA denaturation. DNA from obtained bacterial colonies was extracted using the phenol-chloroform method as previously described (Sambrook et al. 1989). The sample PCR reaction mixture was prepared following Wang \& Qian (2009) in a total reaction volume of $25 \mu \mathrm{l}$. The bacterial 16S rDNA was amplified using the U341F and U1406R primer pair (Wang \& Qian 2009). Amplification by PCR was conducted on a thermal cycler with a heated lid using a cycling program that included an initial denaturation at $94^{\circ} \mathrm{C}$ for $10 \mathrm{~min}$; followed by 35 cycles of denaturation at $94^{\circ} \mathrm{C}$ for $50 \mathrm{~s}$, annealing at $55^{\circ} \mathrm{C}$ for $50 \mathrm{~s}$ and extension at $72^{\circ} \mathrm{C}$ for $1 \mathrm{~min}$. This was followed by additional extension at $72^{\circ} \mathrm{C}$ for $10 \mathrm{~min}$; samples were then held at $4^{\circ} \mathrm{C}$ until the next step in processing. Amplification products were separated by $2 \%$ agarose electrophoresis, stained with a solution of $0.5 \mu \mathrm{g}$ ethidium bromide $\mathrm{ml}^{-1}$ and visualized under UV light using a Chemidoc Image Analyzer (Biorad). PCR products were purified using the Qiaquick PCR purification kit (Qiagen) and sequenced using a MEGABACE 1000 automatic sequencer (Healthcare Biosciences) at the University of La Laguna sequencing services (Servicio General de Apoyo a la Investigación, SEGAI). Obtained sequences were aligned using the MEGA 5.0 software programme (Tamura et al. 2011). Bacterial identification was based on sequence analysis of the amplified region by comparison with available bacterial 16S rDNA sequences in GenBank.

\section{Infection experiments}

Healthy echinoids were collected from 2 sites in the Canary Islands (Boca Cangrejo, Abades; see Fig. 1) in May 2011. D. africanum individuals were divided 
randomly into 4 groups. Sea urchins in the first group ( $\mathrm{n}=16$ individuals) were injected through the peristomal membrane with a small volume $(1 \mathrm{ml})$ of the bacteria isolated in the previous step in a high concentration suspension $\left(10^{4}\right.$ bacteria $\left.\mathrm{ml}^{-1}\right)$. The second group $(n=16)$ were injected with the same volume of suspension containing bacteria at a lesser concentration $\left(4 \times 10^{3}\right.$ bacteria $\left.\mathrm{ml}^{-1}\right)$. To ensure that differences observed were due to the injected agent or its concentration rather than an effect of manipulation, 2 controls were established: a methodological control $(\mathrm{n}=16)$ in which individuals were injected with sterile saline solution and a non-injected control $(\mathrm{n}=16)$. Each treatment/control group was spread between 2 separate 1001 tanks (2 replicates of 8 urchins treatment $^{-1}$ ) with recirculating filtered seawater for $13 \mathrm{~d}$. This experimental design with only 2 replicated tanks with 8 urchins in each treatment was not optimal, but was conducted in this manner due to laboratory space restrictions. Experiments were held at the typical range of seawater temperatures in the season when the disease was detected off the Canary Islands (19.0 to $20.5^{\circ} \mathrm{C}$ ) and monitored daily. Individuals that had lost the ability to attach to the sides/ bottom of the tank and showed clear signs of disease (loss of spines and bald areas on the carapace) were considered morbid and were removed from the tanks.

The number of days each individual survived in healthy condition (without disease symptoms) was measured, and a disease rate was calculated as the total length of the experiment (13 d) minus the survival time $(S)$. A relative disease index (DI) was then computed by dividing the disease rate by the duration of the experiment in days: DI $=(13-S) / 13$. Averages for this index were then calculated for each experimental treatment, producing values between 0 (where there were no diseased urchins over the course of the experiment) and 1 (all individuals were diseased within the first day of the experiment).

\section{Statistical treatment of data}

D. africanum abundances were compared using distance-based permutational analyses of variance (ANOVAs) (Anderson 2004). A 2-way design was conducted when analysing data from Madeira, in which the factor 'Before vs. After' the mortality event was treated as a fixed factor with 2 levels and the factor 'Time' was a random factor with 4 levels nested within 'Before vs. After' (2 sampling times before and 2 after the mortality event). When analysing abundances of the sea urchin in the Canary Islands, a 3-way design was performed in which the factor 'Before vs. After' the mortality event was treated as a fixed factor with 2 levels, 'Island' was a fixed factor with 2 levels (La Palma and Tenerife) and 'Site' was a random factor nested in 'Island' with 12 levels.

Settlement rates of the sea urchin in the Canary Islands were analysed by means of a 2-way distancebased permutational ANOVA. 'Year' was treated as a fixed factor with 5 levels $(2004,2005,2006,2007$ and 2010), and 'Site', as a random factor with 2 levels.

Results of infection experiments with the pathogen were evaluated using a 1-way distance-based permutational ANOVA with the factor 'Treatment' as a fixed factor with 4 levels (injected with bacterial suspension at high concentration, injected with bacterial suspension at low concentration, injected control and non-injected control).

All permutational ANOVAs were based on Euclidian distances among raw data, with 4999 permutations (Anderson 2004), and significant terms in the full models were examined individually using a posteriori pairwise comparisons by permutations (Anderson 2004). Whenever there were not enough possible permutations for a reasonable test, corrected pvalues were obtained through Monte Carlo random draws from the asymptotic permutation distribution (Anderson \& Robinson 2003). The software PRIMER 6 \& PERMANOVA+ was used for all procedures.

Three-month SSTs during the outbreak of the disease (including the month when the disease was detected, the previous and following months) were averaged for each region (Madeira: October, November and December; Canary Islands: February, March and April) and compared to available historical data since the year 1948 (Kalnay et al. 1996).

\section{RESULTS}

\section{Diadema africanum abundances}

In the site at Madeira Island, Diadema africanum abundances were marginally significantly higher before the sea urchin mortality event than in the period just following the event (Table 1A, Fig. 2). The factor 'Time (Before vs. After)' was significant (Table 1A). Different sea urchin densities occurred between the 2 sampling periods performed before the mortality event began (Table 1B, Fig. 2), whereas no differences were found between the 2 periods of sampling after the mortality event (Table 1B, Fig. 2). High SST values $\left(>21.5^{\circ} \mathrm{C}\right)$ were recorded during the months of October to December 2009 in Madeira, coinciding in 
time with the mass mortality event of $D$. africanum (Fig. 3). These values are the highest within the longterm SST dataset dating back to 1948 (Fig. 3).

The interaction of factors 'Before vs. After $\times$ Site (Island)' had a significant effect on the densities of $D$. africanum in the Canary Islands (Table 2A), i.e. urchin abundances varied in response to the mortality event, with different sites showing different responses (Fig. 4). A posteriori pairwise comparisons of the significant interaction showed different trends of change in urchin densities on a local scale (Table 2B). Despite most study sites showing a significant reduction in urchin abundance following the

Table 1. (A) Results of the 2-way distance-based permutational analyses of variance assessing differences in Diadema africanum abundance at Madeira Island between the periods before and after the mortality event and between times studied within each of these periods. (B) Respective pairwise comparisons for the significant factor 'Time (Before vs. After)' are included $\left({ }^{* *} \mathrm{p}<0.01\right)$.

\begin{tabular}{|c|c|c|c|c|c|}
\hline (A) Source of variation & df & SS & MS & Pseudo- $F$ & $\mathrm{p}_{(\text {perm })}$ \\
\hline Before vs. After & 1 & 396.68 & 396.68 & 9.76 & 0.072 \\
\hline Time (Before vs. After) & 2 & 81.25 & 40.62 & 6.77 & $0.002^{* *}$ \\
\hline Residual & 68 & 407.94 & 5.99 & & \\
\hline Total & 71 & 885.88 & & & \\
\hline (B) Pairwise analyses & $t$ & & & $\mathrm{p}_{(\text {perm })}$ & \\
\hline \multicolumn{6}{|l|}{ Before } \\
\hline 21 Jul 1998 vs. 12 Aug 2008 & 3.14 & & & $0.003^{* *}$ & \\
\hline 3 Nov 2009 vs. 24 Nov 2009 & 0.26 & & & 0.810 & \\
\hline
\end{tabular}

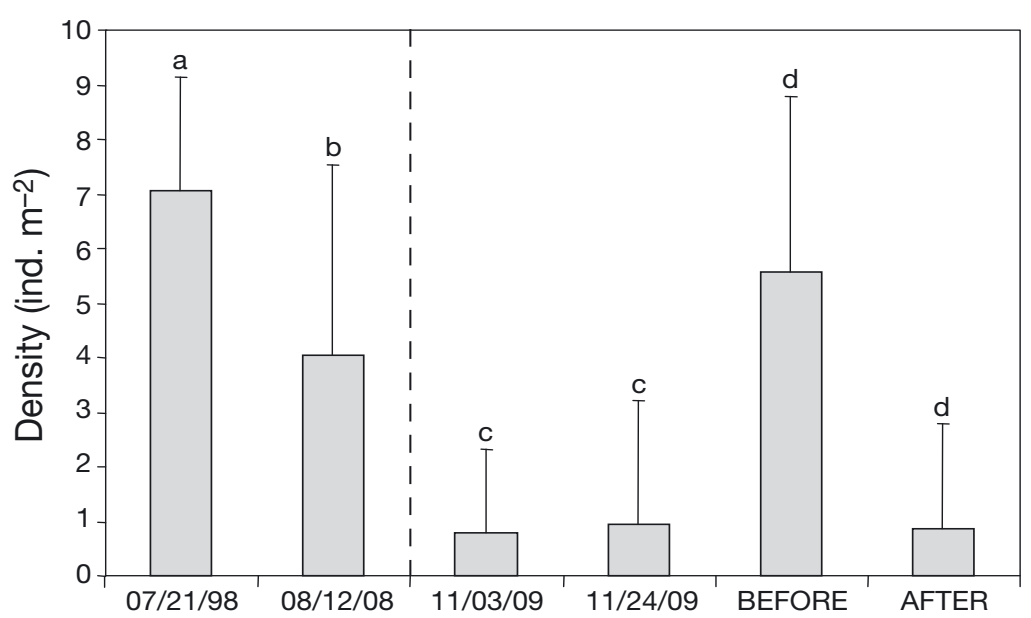

Fig. 2. Diadema africanum. Mean densities $( \pm \mathrm{SE})$ of sea urchins at the study site off Madeira Island (Reis Magos) during 2 periods before (July 1998; August 2008) and 2 periods after (beginning of November 2009; end of November 2009) the observed sea urchin mortality event. Total mean abundances $( \pm \mathrm{SE})$ before and after the outbreak of the disease are included. Different letters show significant differences (pairwise analyses). Vertical dashed line indicates the timing of the mass mortality. Dates given as $\mathrm{mm} / \mathrm{dd} / \mathrm{yy}$ mortality event, 1 site at Tenerife (Teno) showed a marginally non-significant variation in urchin abundance after the mortality event (Table 2B, Fig. 4). In the Canary Islands during the months of February to April 2010, coinciding with the mass mortality, SSTs re the highest on record $\left(>20.4^{\circ} \mathrm{C}\right)$ in the existing dataset of SST measurements (Fig. 3).

\section{D. africanum settlement in the Canary Islands}

The settlement peak of D. africanum in 2010 at study sites around the Canary Islands was consistent with results obtained in previous years (Fig. 5). Newly metamorphosed juveniles of the echinoid were collected during the period from August to October 2010 at both study sites following the mass mortality event, which took place $\sim 6$ mo earlier (Fig. 5). Non-significant differences were detected between the settlement rate in 2010 and those recorded in years prior to the mass mortality. There was no significant effect of the interaction of the factors 'Year $\times$ Site' (Table 3, Fig. 5) . However, variability in settlement rates was observed between sites (Table 3); the number of settled sea urchins was consistently higher at Abades than at Boca Cangrejo for the whole study period (Fig. 5).

\section{Pathogen identification}

Bacterial growth was only detected in the TCBS agar plates. Both green and yellow colonies were observed on these plates, indicating the presence of Vibrio sp. Yellow colonies were more abundant in samples taken from sea urchins displaying external symptoms of disease (positive in $92.9 \%$ of plates) compared with samples from sea urchins without any external symptoms (positive in $12.2 \%$ of plates) (Table 4). As per manufacturers' instructions, the presence of yellow colonies shows the presence of the species Vibrio alginolyticus. In order to confirm these results we performed PCR amplification and sequencing of the obtained fragments; the sequencing results confirmed the identity of the isolated colonies as $V$. alginolyticus. 
Fig. 3. Mean seasonal sea-surface temperatures (SST) around (A) Madeira Island and (B) the Canary Islands, from 1947 to 2010. Season chosen for each region coincides with the time of the year when the sea urchin disease outbreak was detected: October to December for Madeira (A) and February to April for the Canary Islands (B). Open circles show SST during the occurrence of the Diadema africanum mass mortality event at each location. All SST data were obtained from Kalnay et al.'s (1996) reanalysis

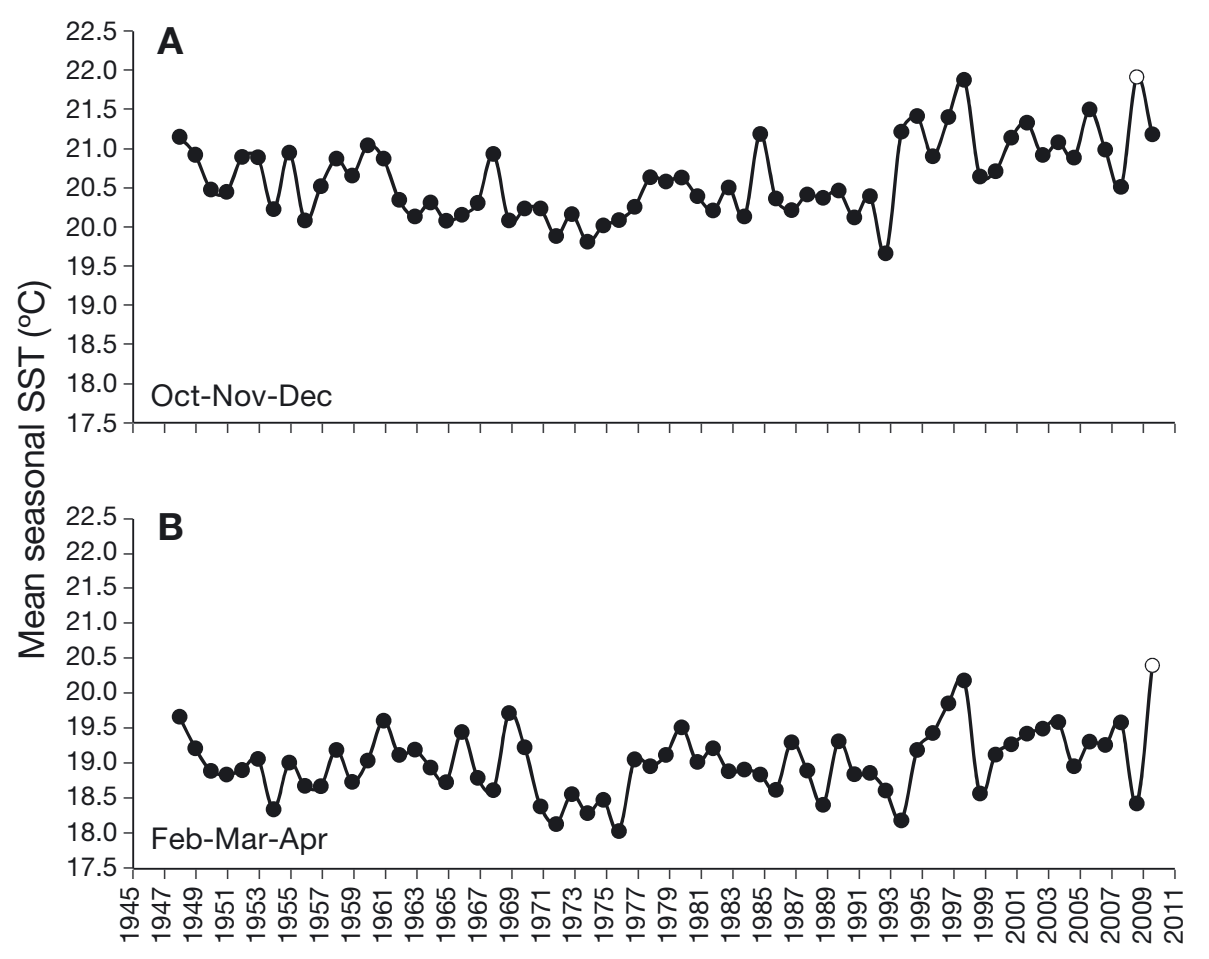

Table 2. (A) Results of the 3-way distance-based permutational analyses of variance assessing differences in Diadema africanum abundance in the Canary Islands between the periods before and after the mortality event, between 2 islands (La Palma and Tenerife) and between sites studied at each island. (B) Estimates for pairwise comparisons for the significant interaction 'Before vs. After $\times$ Site (Island)', showing differences before and after the mortality event at sites at each of the studied islands $\left({ }^{*} \mathrm{p}<\right.$ $\left.0.05 ;{ }^{* *} \mathrm{p}<0.01\right)$

\begin{tabular}{|c|c|c|c|c|c|}
\hline (A) Source of variation & df & SS & MS & Pseudo- $F$ & $\mathrm{p}_{(\text {perm })}$ \\
\hline Before vs. After & 1 & 922.40 & 922.40 & 69.37 & $0.001^{* *}$ \\
\hline Island & 1 & 84.32 & 84.32 & 1.43 & 0.276 \\
\hline Site (Island) & 10 & 593.25 & 59.32 & 19.26 & $0.001^{* *}$ \\
\hline Before vs. After $\times$ Island & 1 & 9.44 & 9.44 & 0.71 & 0.399 \\
\hline Before vs. After $\times$ Site (Island) & 10 & 133.57 & 13.36 & 4.34 & $0.001^{* *}$ \\
\hline Residual & 183 & 563.74 & 3.08 & & \\
\hline Total & 206 & 2324.40 & & & \\
\hline (B) Pairwise analyses & $t$ & & & $\mathrm{p}_{(\text {perm })}$ & \\
\hline \multicolumn{6}{|l|}{ La Palma Island } \\
\hline Playa del Pozo & 5.90 & & & $0.001^{* *}$ & \\
\hline Punta del Fraile & 4.92 & & & $0.001^{* *}$ & \\
\hline Los Cancajos & 4.91 & & & $0.001^{* *}$ & \\
\hline Fuencaliente & 3.15 & & & $0.007^{* *}$ & \\
\hline Puerto Naos & 9.16 & & & $0.001^{* *}$ & \\
\hline La Bombilla & 10.21 & & & $0.001^{* *}$ & \\
\hline \multicolumn{6}{|l|}{ Tenerife Island } \\
\hline Boca Cangrejo & 2.22 & & & $0.039^{*}$ & \\
\hline Punta Prieta & 6.89 & & & $0.001^{* *}$ & \\
\hline El Porís & 7.63 & & & $0.001^{* *}$ & \\
\hline Abades & 5.29 & & & $0.001^{* *}$ & \\
\hline La Caleta de Adeje & 6.83 & & & $0.001^{* *}$ & \\
\hline Teno & 1.81 & & & 0.079 & \\
\hline
\end{tabular}

\section{Infection experiments}

By injecting sea urchins with different concentrations of the bacteria Vibrio alginolyticus we found that the 4 different experimental treatments had a significant effect on relative disease index (Table 5). A posteriori pairwise comparisons showed that the disease indices were significantly higher in sea urchins injected with the pathogen (both high and low concentrations) compared with the injected (with sterile saline solution) and non-injected controls (Table 5, Fig. 6). No significant differences were found between individuals injected with bacteria at high concentration compared to low concentration; neither were there significant differences between the 2 control groups (Table 5, Fig. 6). Mortality at $13 \mathrm{~d}$ after inoculation was $56.3 \%$ of the individuals in the group injected with a high concentration of the pathogen and $37.5 \%$ in the group injected with the pathogen at a lower concentration. In both control groups no urchin mortality occurred as a result of the disease (Fig. 6). 


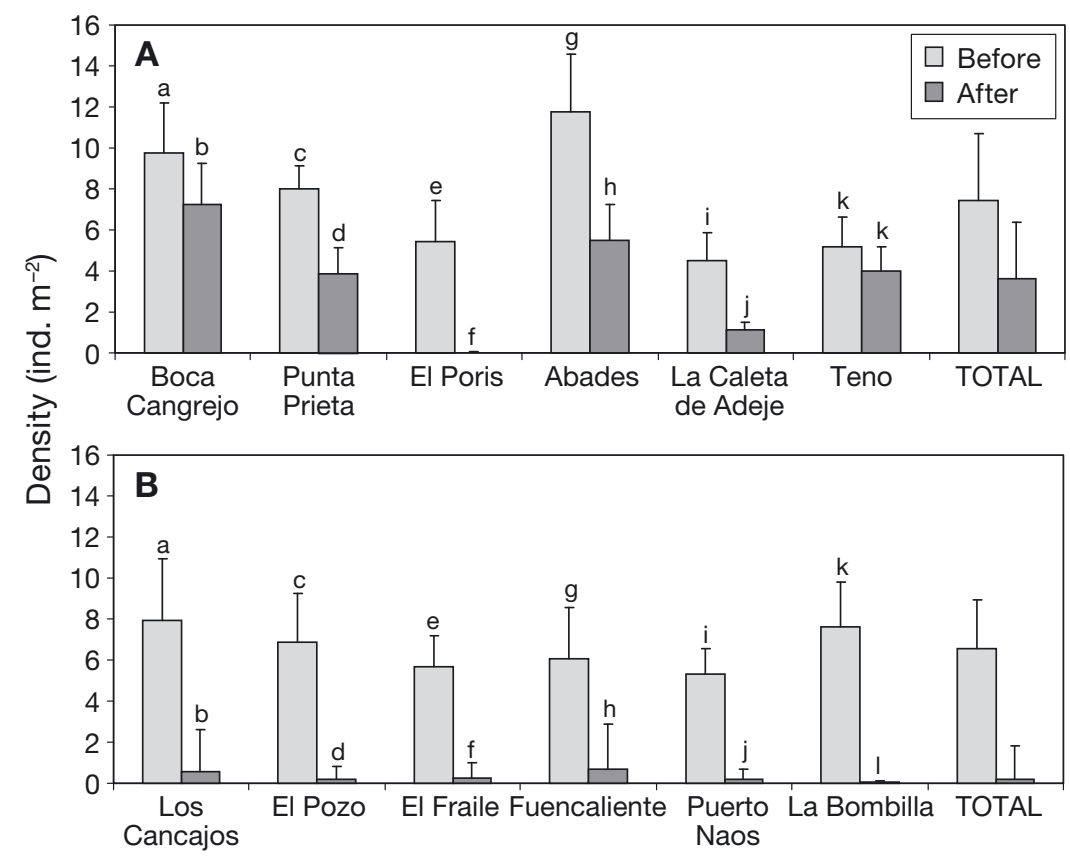

Fig. 4. Diadema africanum. Mean densities $( \pm$ SE) of sea urchins before and after the observed mortality event at each study site around the Canary Islands: (A) Tenerife Island and (B) La Palma Island. Total mean abundances $( \pm \mathrm{SE})$ are shown before and after the outbreak of the disease for each island. Different letters show significant differences (pairwise analyses, $\mathrm{p}<0.05$ )
The mortality episode was spread across a latitudinal range from Madeira Island $\left(32.8^{\circ} \mathrm{N}\right)$ to the Canary Islands $\left(27.3^{\circ} \mathrm{N}\right)$, covering a straightline distance of more than $400 \mathrm{~km}$. The 2 locations are connected by the Canary Current, a wind-driven surface current that is part of the North Atlantic Gyre and flows from north to south along the African coast (Couvelard et al. 2012). This event constitutes the first documented widespread die-off of a diadematid species due to disease in the eastern Atlantic Ocean.

D. africanum is a recognized key herbivore and controls the predominance of algal stands in sublittoral rocky bottom habitats (Alves et al. 2003, Hernández et al. 2008b). Disease is one of the few natural mechanisms known to cause sea urchin mass mortalities (Feehan et al. 2012); therefore, studies of these events are necessary to better understand the mechanisms that mediate transitions

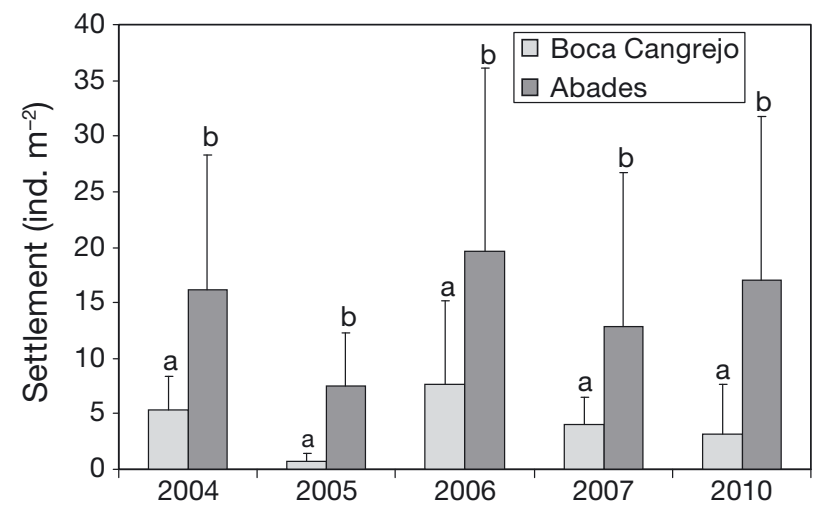

Fig. 5. Diadema africanum. Mean abundances $( \pm$ SE) of early settled sea urchins at 2 study sites at Tenerife, Canary Islands. Settlement rates are given for 5 years (before the mortality event: 2004, 2005, 2006, 2007; after the mortality event: 2010). Different letters show significant differences (pairwise analyses, $\mathrm{p}<0.05)$. Data from Hernández et al. (2010) for the years 2004 to 2007 are included in the analysis

\section{DISCUSSION}

We have reported the first record of a mass mortality event affecting the sea urchin Diadema africanum in subtropical waters of the eastern Atlantic. The mortality event was observed from October 2009 to April 2010 in 2 archipelagos in the eastern Atlantic. between alternate ecosystem states in benthic systems. Disease-mediated control of urchin populations alleviates the grazing pressure on macroalgal beds and enable macroalgal growth and subsequent colonization of rocky areas (Scheibling 1984, Lafferty 2004).

Throughout the study sites anomalous accumulations of moribund sea urchins and tests of dead individuals were recorded on the bottom (Fig. 7). The disease in $D$. africanum was characterized by progressive deterioration of the epidermis of the body wall and water-vascular system in individuals, resulting in epidermal necrosis, loss of tube feet function and release of spines. Diseased sea urchins were unable to firmly attach to the substratum and ceased to move, which impaired feeding and made them more susceptible to predation (authors' pers. obs.). These symptoms are similar to those previously reported for sea urchin mass mortalities elsewhere (Scheibling \& Stephenson 1984, Roberts-Regan et al. 1988, Benítez-Villalobos et al. 2009, Girard et al. 2012).

The short-term ecological effect of the $D$. africanum mass mortality event was a decrease in mean sea urchin density. Overall abundance dropped to $65 \%$ of the pre-mortality value, though the incidence of mortality varied between sites. The scarcity of pre- 
Table 3. Results of the 2-way distance-based permutational analyses of variance assessing differences in the abundance of early settled Diadema africanum around Tenerife Island. Settlement rates were compared for 5 years (before the mortality event: 2004, 2005, 2006, 2007; after the mortality event: 2010$)$ and 2 study sites $\left({ }^{* *} \mathrm{p}<0.01\right)$

\begin{tabular}{|lrrrrl|}
\hline Source of variation & df & \multicolumn{1}{c}{ SS } & \multicolumn{1}{c|}{ MS } & Pseudo- $F$ & $\mathrm{p}_{\text {(perm) }}$ \\
\hline Year & 4 & 700.55 & 175.14 & 6.63 & 0.081 \\
Site & 1 & 2138.80 & 2138.80 & 20.55 & $0.001^{* *}$ \\
Year $\times$ Site & 4 & 105.70 & 26.42 & 0.25 & 0.897 \\
Residual & 71 & 7388.90 & 104.07 & & \\
Total & 80 & 10479.00 & & & \\
\hline
\end{tabular}

Table 4. Bacterial screening results for Diadema africanum; both individuals with external symptoms of disease and individuals without external symptoms. Provided are the raw numbers and prevalence of individuals (\%) testing positive and negative for bacterial growth in media specific for the isolation of Vibrio spp. (TCBS agar, Merck). A description of bacterial growth is given in each case

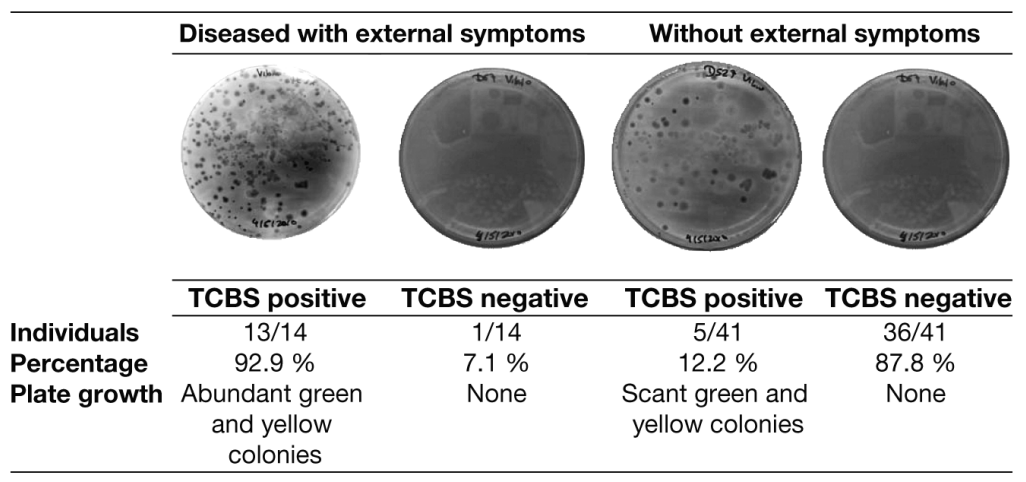

Table 5. (A) Results of the 1-way distance-based permutational analyses of variance assessing differences in the disease rate of Diadema africanum in laboratory infection experiments with the pathogenic bacteria Vibrio alginolyticus. Comparisons are between experimental treatments (high bacterial concentration, low bacterial concentration, injected control and non-injected control). (B) Respective pairwise comparisons for the significant factor 'Treatment' are included $\left({ }^{*} \mathrm{p}<0.05{ }^{*}{ }^{* *} \mathrm{p}<0.01\right)$

\begin{tabular}{|lccccc|}
\hline (A) Source of variation & df & SS & MS & Pseudo- $F$ & $\mathrm{p}_{(\text {perm })}$ \\
\hline Treatment & 3 & 0.41 & 0.14 & 4.81 & $0.003^{* *}$ \\
Residual & 60 & 1.73 & 0.03 & & \\
Total & 63 & 2.14 & & & \\
\hline (B) Pairwise comparisons & & & $t$ & $\mathrm{p}_{(\text {perm })}$ \\
\hline High concentration vs. & Low concentration & 1.02 & 0.337 \\
& Injected control & 3.12 & $0.002^{* *}$ \\
Low concentration vs. & Non-injected control & 3.12 & $0.002^{* *}$ \\
Injected control & 1.81 & $0.052^{*}$ \\
Injected control vs. & Non-injected control & 1.81 & $0.043^{*}$ \\
& Non-injected control & 0.00 & 1.000 \\
\hline
\end{tabular}

mortality data in Madeira prevented an in-depth analysis of the incidence of disease on populations around the island, so its effects on the stability of this system remain largely unknown; however, recent observational data suggest a recovery of $D$. africanum abundances in the affected areas (F. Alves pers. obs.). Still, observed diseased individuals around Madeira and the Canarian Islands demonstrate the geographical scale of the mortality event, which extended across $5^{\circ}$ of latitude. Other large-scale mortality events have been observed along the coast of Nova Scotia, Canada (Miller \& Colodey 1983, Jones \& Scheibling 1985) and in the Caribbean (Lessios 1988). Most of the study sites off the Canarian Archipelago showed significantly lower urchin densities after the mortality event than in the period just preceding it, with the exception of 1 site, at which the decrease was marginally non-significant. Seawater residence times may be lower at this specific site due to its location on the northwest coast of Tenerife, which is more exposed to trade winds and NNW-NW swells, resulting in a lower transmission of the waterborne disease. Long seawater residence times in protected locations are linked to higher levels of disease outbreak (Feehan et al. 2012).

Despite the spatial heterogeneity, our results give strong evidence that the documented mortality event affects the short-term (months to a few years) stability of urchin populations. Given the well-known negative relationships between erect algal beds and herbivorous sea urchins (Hernández et al. 2008b, Sangil et al. 2011), such an event may determine the stability of the community or even drive the transition to a macroalga-dominated system. The ecological effects of the mortality event still need to be investigated on a longer time scale to provide insight into the mechanisms driving ecosystem dynamics. However, $\sim 40 \%$ of the $D$. africanum population survived the mortality event, and the reduction in urchin abundance did 


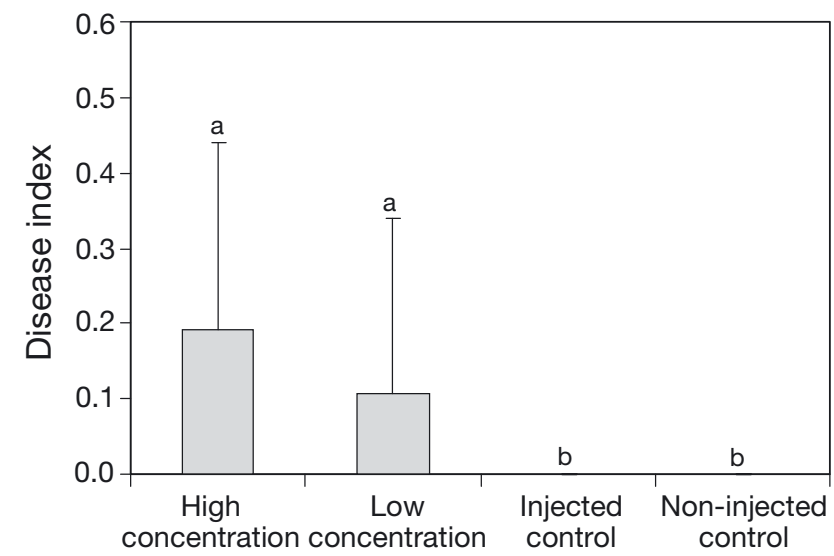

Fig. 6. Diadema africanum. Mean disease index $( \pm \mathrm{SE})$ in laboratory infection experiments with the pathogenic bacteria Vibrio alginolyticus. Comparisons are between experimental treatments (high bacterial concentration, low bacterial concentration, injected control and non-injected control). Different letters show significant differences (pairwise analyses, $\mathrm{p}<0.05$ )

not compromise the reproductive success of the species, which had a subsequent settlement peak of a similar magnitude to that observed in years prior to the mortality event. This, together with the high sitespecific variability on the incidence of the disease (probably related to seawater residence times) and the fact that only populations at depths of 5 to $15 \mathrm{~m}$ were sampled, suggests the existence of refuge populations at specific sites and at greater depths. Results, therefore, indicate a generally rapid recovery of populations and suggest that barren ground habitat is very resilient. However, further observations showed macroalgal regrowth or phase-shift at specific barren grounds, where sea urchin densities dropped below 2 ind. $\mathrm{m}^{-2}$ due to the mortality event. Following this decrease in urchin abundances at specific spots, we observed slow colonization of empty spaces by fucoid algae (Sargassum sp. and Cystoseira compressa), populations of which persisted for at least 2 yr (C. Sangil pers. obs.).

Establishing the causative agents of a mass mortality event can be difficult to achieve. However, in this study, we provide strong experimental evidence that a bacterial pathogen was involved in the event. Bacterial infections have caused mass mortalities of echinoids in several different species and regions: Paracentrotus lividus in the Mediterranean (Boudouresque \& Verlaque 2007) and Strongylocentrotus franciscanus and S. purpuratus (Lafferty 2004, Rogers-Bennett 2007) in the Pacific Ocean. Within this study internal pathogens were isolated from the coelomic fluid of $D$. africanum individuals, and all but 1 diseased individ-

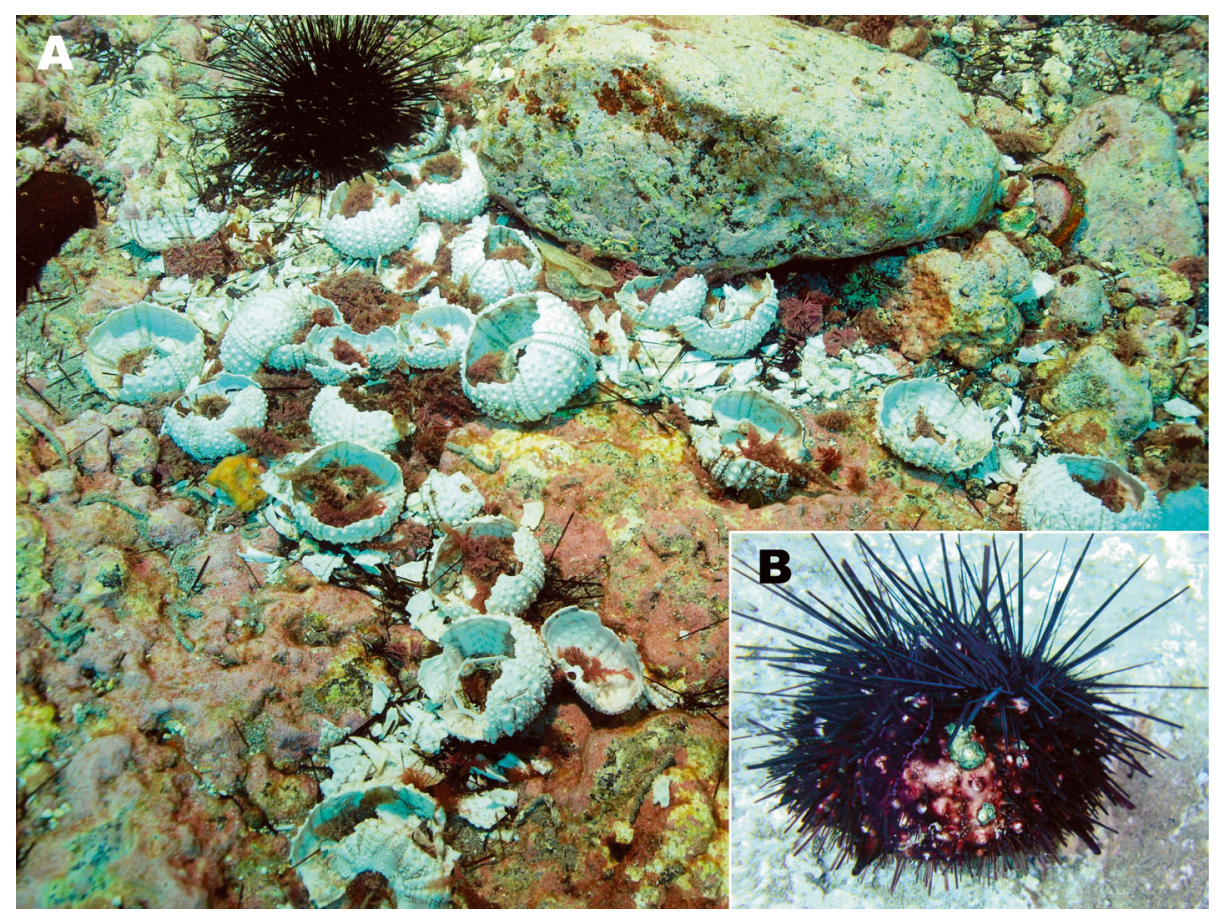

Fig. 7. Diadema africanum. (A) Typical anomalous accumulations of moribund sea urchins and tests of dead individuals recorded during the mass mortality event. (B) A diseased individual displaying deterioration of the epidermis of the body wall, epidermal necrosis and loss of the tube feet and spines. Pictures were taken in the Canary Islands. Images: (A) C. Sangil,

(B) J. C. Hernández 
ual was positive for Vibrio alginolyticus. A much lower proportion of sea urchin individuals without external symptoms of disease were found to contain the bacteria $(12.2 \%)$. The capability of $V$. alginolyticus to cause disease symptoms was corroborated with subsequent infection experiments in the laboratory, using the isolated pathogen; sea urchins injected with the pathogen displayed higher mortality rates relative to controls.

Healthy sea urchins have sterile coelomic fluid (Bang \& Lemma 1962, Wardlaw \& Unkles 1978), due to the bactericidal properties of the internal fluid and by the phagocytizing activity of coelomocytes (Bauer \& Young 2000, and references therein). Yet our results show the occurrence of individuals carrying the pathogen in their coelomic fluid without showing external symptoms of disease. Similarly, a proportion of the healthy individuals that were experimentally injected with a suspension containing the pathogen did not develop the disease during the course of the infection experiments. Overall mortality of experimental individuals at $13 \mathrm{~d}$ after inoculation was around $38 \%$ in the group injected with a low concentration of the pathogen and $57 \%$ in the group injected with the pathogen at a higher concentration, probably due to dosage dependence. This experiment does not rule out the possibility of synergy between the isolated species of bacteria and other pathogens in the development of the disease. A parallel study conducted with $D$. africanum showed the presence of free-living amoebae in the coelomic fluid of diseased individuals (Dyková et al. 2011), but such amoebae have also been isolated from healthy individuals of 2 other sea urchin species (Paracentrotus lividus and Heliocidaris erythrogramma; Dyková et al. 2007). Therefore, those authors argued that Neoparamoeba branchiphila (which has recently been suggested as Paramoeba branchiphila comb. nov. based on evidence from analysis of SSU rDNA; Feehan et al. 2013) either caused the observed disease in D. africanum or contributed to it. Considering this previous information, our study supports the hypothesis that the amoeba $N$. branchiphila may play an opportunistic role, given that experimental injection of $V$. alginolyticus caused disease symptoms in $D$. africanum. A synergy between the amoeba and the bacteria $V$. alginolyticus may be involved in the development of this sea urchin disease. On the other hand, Kaufmann \& Böhm-Beck (2013) recorded a bloom of toxic epibenthic dinoflagellates (Ostreopsis sp.) on the southern and south-eastern coasts of Madeira, co-occurring with the sea urchin mortality event in time and space. Specifically, those authors found high cell numbers of the dinoflagellate at the site Reis Magos, growing on thin layers or over turf macroalgae. Disease and mortality of a variety of marine organisms, including sea urchins, has previously occurred during blooms of dinoflagellates (Shears \& Ross 2009, and references therein), so it is also plausible that the potent toxins produced by Ostreopsis sp. deteriorate the sea urchin immune system, allowing subsequent opportunistic infections by other pathogens. Further studies should evaluate the role of all these pathogens (amoeba, dinoflagellates and bacteria) simultaneously in order to determine the primary agent of $D$. africanum mortality. Nevertheless, the importance of habitat features for the occurrence of harmful algal blooms should be carefully considered before any conclusions are drawn: for example, macroalgal substrates known to promote blooms of Ostreopsis sp. and other harmful algal species elsewhere (e.g. Mangialajo et al. 2008, Shears \& Ross 2009) are very limited in the barren grounds off the Canary Islands (Hernández et al. 2008b).

Seawater is an important vehicle of transmission for bacteria, which accounts for their cosmopolitan range and spread among marine invertebrates (Bauer \& Young 2000). Disease events are becoming more frequent as a result of ongoing changes in seawater conditions that facilitate the propagation of pathogens (Scheibling \& Lauzon-Guay 2010, Feehan et al. 2012). For instance, temperature is key in regulating the transmission and development of paramoebiasis in Strongylocentrotus droebachiensis (Scheibling \& Stephenson 1984, Jellett \& Scheibling 1988), and peak occurrences of the disease coincide with peaks in SST in warmer years (Miller \& Colodey 1983, Scheibling \& Stephenson 1984, Scheibling \& Lauzon-Guay 2010, Feehan et al. 2012). Populations of Paracentrotus lividus in the intertidal habitats around the Canary Islands also experienced an outbreak of bald sea urchin disease, which corresponded with a period of high temperatures (Girard et al. 2012). High SSTs resulting from climatic changes often promote the occurrence of disease (Harvell et al. 1999, Lafferty et al. 2004) by reducing pathogen resistance in echinoids (Azzolina 1983, Scheibling \& Stephenson 1984, Miller 1985), and may have also aided the development of the disease outbreak in D. africanum in the eastern Atlantic described herein. Under the current scenario of seawater warming shown for the region (see also Hernández et al. 2010) and elsewhere, we would expect urchin abundance to become progressively more disease-mediated as seawater temperatures warm over time. This pattern of disease-mediated 
control is likely to favour phase shifts that may eventually lead to the persistence of macroalgae in previously barren areas of rocky habitat (see also Scheibling et al. 2013). However, further laboratory experiments would be desirable to test sea urchin infection rates at various seawater temperatures.

In view of the important role of $D$. africanum in the eastern Atlantic (Hernández et al. 2008b), the repercussions of mass mortality events affecting the sea urchin are likely to be far-reaching and affect the stability of subtidal ecosystems, especially if these events become more frequent in the future. Nevertheless, the great reproductive potential of the species (Hernández et al. 2011) is a clear advantage for population recovery in the short term, and the long-term response of the species to potential temperaturedriven disease events remains to be seen. The reported disease outbreak and short-term response to this mortality event add to a wider understanding of the factors controlling fluctuations in sea urchin population size, a key process influencing the structure and functioning of the benthic ecosystem.

Acknowledgements. A. Rodríguez, A. Glockner and L. Martín helped during laboratory experiments and field data collections in the Canary Islands. Thanks to M. Maranhão for helping with data collection in Madeira. J. Manning improved an earlier version of the manuscript. 'Gobierno de Canarias' provided financial support for the study. S.C. benefited from a postdoctoral fellowship within the 'CEICanarias, Campus Atlántico Tricontinental' supported by the Spanish 'Ministerio de Ciencia e Innovación' and 'Ministerio de Educación'. J.L.M. was supported by the 'Ramón y Cajal' subprogramme of the Spanish 'Ministerio de Economía y Competitividad' (RYC-2011-08863).

\section{LITERATURE CITED}

Alves FMA, Chícharo LM, Serrão E, Abreu AD (2001) Algal cover and sea urchin spatial distribution at Madeira Island (NE Atlantic). Sci Mar 65:383-392

- Alves FMA, Chícharo LM, Serrão E, Abreu AD (2003) Grazing by Diadema antillarum (Philippi) upon algal communities on rocky substrates. Sci Mar 67:307-311

Anderson MJ (2004) PERMANOVA 2factor: a FORTRAN computer program for permutational multivariate analysis of variance using permutation tests. University of Auckland

Anderson MJ, Robinson J (2003) Generalised discriminant analysis based on distances. Aust NZ J Stat 45:301-318

Azzolina JF (1983) Evolution de la maladie de l'oursin comestible Paracentrotus lividus dans la baie de PortCros (Var, France). Rapp PV Reun Comm Int Explor Sci Mer Mediter Monaco 28:263-264

Bang FB, Lemma A (1962) Bacterial infection and reaction to injury in some echinoderms. J Insect Pathol 4:401-414

Bauer JC, Young CM (2000) Epidermal lesions and mortality caused by vibriosis in deep-sea Bahamian echinoids: a laboratory study. Dis Aquat Org 39:193-199

Benítez-Villalobos F, Díaz Martínez JP, Martínez-García M (2009) Mass mortality of the sea urchin Diadema mexicanum in La Entrega at Bahias de Huatulco, western Mexico. Coral Reefs 28:1017

Boudouresque CF, Verlaque M (2007) Ecology of Paracentrotus lividus. In: Lawrence JM (ed) Edible sea urchins: biology and ecology. Elsevier, Amsterdam, p 243-285

> Couvelard X, Caldeira RMA, Araujo IB, Tome R (2012) Wind mediated vorticity-generation and eddy-confinement, leeward of the Madeira Island: 2008 numerical case study. Dyn Atmos Oceans 58:128-149

> Dyková I, Nowak B, Pecková H, Fiala I, Crosbie P, Dvoráková H (2007) Phylogeny of Neoparamoeba strains isolated from marine fish and invertebrates as inferred from SSU rDNA sequences. Dis Aquat Org 74:57-65

Dyková I, Lorenzo-Morales J, Kostka M, Valladares B, Pecková H (2011) Neoparamoeba branchiphila infections in moribund sea urchins Diadema aff. antillarum in Tenerife, Canary Islands, Spain. Dis Aquat Org 95:225-231

Ebert TA (2013) Temporal changes in the sea urchin Strongylocentrotus purpuratus along the west coast of North America. In: Fernández-Palacios JM, Nascimento L, Hernández JC, Clemente S, González A, Díaz JP (eds) Climate change perspectives from the Atlantic: past, present and future. Servicio de Publicaciones, Universidad de La Laguna, p 443-460

- Edmunds PJ, Carpenter RC (2001) Recovery of Diadema antillarum reduces macroalgal cover and increases abundance of juvenile corals on a Caribbean Reef. Proc Natl Acad Sci USA 98:5067-5071

Epstein P (1996) Emergent stressors and public health implications in large marine ecosystems: an overview. In: Sherman K, Jaworski NA, Smayda TJ (eds) The northeast shelf ecosystem: assessment, sustainability, and management. Blackwell, Cambridge, MA, p 417-438

> Feehan C, Scheibling RE, Lauzon-Guay JS (2012) An outbreak of sea urchin disease associated with a recent hurricane: support for the 'killer storm hypothesis' on a local scale. J Exp Mar Biol Ecol 413:159-168

> Feehan CJ, Johnson-Mackinnon J, Scheibling RE, LauzonGuay JS, Simpson AGB (2013) Validating the identity of Paramoeba invadens, the causative agent of recurrent mass mortality of sea urchins in Nova Scotia, Canada. Dis Aquat Org 103:209-227

Girard D, Clemente S, Toledo-Guedes K, Brito A, Hernández JC (2012) A mass mortality of subtropical intertidal populations of the sea urchin Paracentrotus lividus: analysis of potential links with environmental conditions. Mar Ecol 33:377-385

Goreau TJ, Cervino J, Goreau M, Hayes R, Hayes M (1998) Rapid spread of diseases in Caribbean coral reefs. Rev Biol Trop 46:157-171

Harrold C, Lisin S, Light KH, Tudor S (1991) Isolating settlement from recruitment of sea urchins. J Exp Mar Biol Ecol 147:81-94

Harvell CD, Kim K, Burkholder JM, Colwell RR and others (1999) Emerging marine diseases—climate links and anthropogenic factors. Science 285:1505-1510

Harvell CD, Mitchell CE, Ward JR, Altizer S, Dobson AP, Ostfeld RS, Samuel MD (2002) Climate warming and disease risks for terrestrial and marine biota. Science 296: 2158-2162 
Hayes ML, Bonaventura J, Mitchell TP, Prospero JM, Shinn EA (2001) How are climate and marine biological outbreaks functionally linked? Hydrobiologia 460:213-220

Hendler G (2013) Recent mass mortality of Strongylocentrotus purpuratus (Echinodermata: Echinoidea) at Malibu and a review of purple sea urchin kills elsewhere in California. Bull South Calif Acad Sci 112:19-37

Hernández JC, Brito A, Cubero E, Girard D, GonzálezLorenzo G, Falcón JM (2006) Temporal patterns of larval settlement of Diadema antillarum (Echinodermata: Echinoidea) in the Canary Islands using an experimental larval collector. Bull Mar Sci 78:271-279

> Hernández JC, Clemente S, Sangil C, Brito A (2008a) Actual status of the sea urchin Diadema aff. antillarum populations and macroalgal cover in the Marine Protected Areas comparing to a highly fished area (Canary IslandsEastern Atlantic Ocean). Aquat Conserv 18:1091-1108

> Hernández JC, Clemente S, Sangil C, Brito A (2008b) The key role of the sea urchin Diadema aff. antillarum in controlling macroalgae assemblages throughout the Canary Islands (eastern subtropical Atlantic): a spatio-temporal approach. Mar Environ Res 66:259-270

- Hernández JC, Clemente S, Girard D, Pérez-Ruzafa A, Brito A (2010) Effect of temperature on settlement and postsettlement survival in a barrens-forming sea urchin. Mar Ecol Prog Ser 413:69-80

Hernández JC, Clemente S, Brito A (2011) Effects of seasonality on the reproductive cycle of Diadema aff. antillarum in two contrasting habitats: implications for the establishment of a sea urchin fishery. Mar Biol 158:2603-2615

Hoegh-Guldberg O (1999) Climate change, coral bleaching and the future of the world's coral reefs. Mar Freshw Res 50:839-866

> Jellett JF, Scheibling RE (1988) Effect of temperature and prey availability on growth of Paramoeba invadens in monoxenic culture. Appl Environ Microbiol 54:1848-1854

> Jones GM, Scheibling RE (1985) Paramoeba sp. (Amoebida, Paramoebidae) as the possible causative agent of sea urchin mass mortality in Nova Scotia. J Parasitol 71: 559-565

Kalnay E, Kanamitsu M, Kistler R, Collins W and others (1996) The NCEP/NCAR reanalysis 40-years project. Bull Am Meteorol Soc 77:437-471

Kaufmann M, Böhm-Beck M (2013) Gambierdiscus and related benthic dinoflagellates from Madeira archipelago (NE Atlantic). Harmful Algae News 47:18-19

Khouadja S, Lamari F, Bakhrouf A (2013) Characterization of Vibrio parahaemolyticus isolated from farmed sea bass (Dicentrarchus labrax) during disease outbreaks. Int Aquat Res 5:13

$>$ Lafferty KD (2004) Fishing for lobsters indirectly increases epidemics in sea urchins. Ecol Appl 14:1566-1573

> Lafferty KD, Porter JW, Ford SE (2004) Are diseases increasing in the ocean? Annu Rev Ecol Evol Syst 35:31-54

Lessios HA (1988) Population dynamics of Diadema antillarum (Echinodermata: Echinoidea) following mass mortality in Panama. Mar Biol 99:515-526

Lessios HA (1995) Diadema antillarum 10 years after mass mortality: still rare, despite help from a competitor. Proc R Soc Lond B Biol Sci 259:331-337

Levitan D (1988) Density-dependent size regulation and negative growth in the sea urchin Diadema antillarum Philippi. Oecologia 76:627-629

Mangialajo L, Bertolotto R, Cattaneo-Vietti R, Chiantore M and others (2008) The toxic benthic dinoflagellate Ostreopsis ovata: quantification of proliferation along the coastline of Genoa, Italy. Mar Pollut Bull 56:1209-1214

Miller RJ (1985) Succession in sea urchin and seaweed abundance in Nova Scotia, Canada. Mar Biol 84:275-286

Miller RJ, Colodey AG (1983) Widespread mass mortalities of the green sea urchin in Nova Scotia, Canada. Mar Biol 73:263-267

Porter JW, Dustan P, Jaap WC, Patterson KL, Kosmynin V (2001) Patterns of spread of coral disease in the Florida Keys. Hydrobiologia 460:1-24

Roberts-Regan DL, Scheibling RE, Jellett JF (1988) Natural and experimentally induced lesions of the body wall of the sea urchin Strongylocentrotus droebachiensis. Dis Aquat Org 5:51-62

> Rodríguez A, Hernández JC, Clemente S, Coppard SE (2013) A new species of Diadema (Echinodermata: Echinoidea: Diadematidae) from the eastern Atlantic Ocean and a neotype designation of Diadema antillarum (Philippi, 1845). Zootaxa 3636:144-170

Rogers-Bennett L (2007) The ecology of Strongylocentrotus franciscanus and Strongylocentrotus purpuratus. In: Lawrence JM (ed) Edible sea urchins: biology and ecology. Elsevier, Amsterdam, p 393-425

Sambrook J, Fritsch EF, Maniatis T (1989) Molecular cloning: a laboratory manual, 2nd edn. Cold Spring Harbor Laboratory Press, New York, NY

Sangil C, Sansón M, Carrillo JA (2011) Spatial variation patterns of subtidal seaweed assemblages along a subtropical oceanic archipelago: thermal gradient vs herbivore pressure. Estuar Coast Shelf Sci 94:322-333

Scheibling RE (1984) Echinoids, epizootics and ecological stability in the rocky subtidal off Nova Scotia, Canada. Helgol Meeresunters 37:233-242

Scheibling RE, Hennigar AW (1997) Recurrent outbreaks of disease in sea urchins Strongylocentrotus droebachiensis in Nova Scotia: evidence for a link with large-scale meteorologic and oceanographic events. Mar Ecol Prog Ser 152:155-165

> Scheibling RE, Lauzon-Guay JS (2010) Killer storms: North Atlantic hurricanes and disease outbreaks in sea urchins. Limnol Oceanogr 55:2331-2338

Scheibling RE, Stephenson RL (1984) Mass mortality of Strongylocentrotus droebachiensis (Echinodermata: Echinoidea) off Nova Scotia, Canada. Mar Biol 78: 153-164

Scheibling RE, Feehan C, Lauzon-Guay JS (2010) Disease outbreaks associated with recent hurricanes cause mass mortality of sea urchins in Nova Scotia. Mar Ecol Prog Ser 408:109-116

Scheibling RE, Feehan CJ, Lauzon-Guay JS (2013) Climate change, disease and the dynamics of a kelp-bed ecosystem in Nova Scotia. In: Fernández-Palacios JM, de Nascimento L, Hernández JC, Clemente S, González A, Díaz JP (eds) Climate change perspectives from the Atlantic: past, present and future. Servicio de Publicaciones, Universidad de La Laguna, p 361-387

Shears NT, Ross PM (2009) Blooms of benthic dinoflagellates of the genus Ostreopsis; an increasing and ecologically important phenomenon on temperate reefs in New Zealand and worldwide. Harmful Algae 8:916-925

Tamura K, Peterson D, Peterson N, Stecher G, Nei M, Kumar S (2011) MEGA5: molecular evolutionary genetics analysis using maximum likelihood, evolutionary distance, 
and maximum parsimony methods. Mol Biol Evol 28: 2731-2739

> Wang Y, Qian PY (2009) Conservative fragments in bacterial 16S rRNA genes and primer design for $16 \mathrm{~S}$ ribosomal DNA amplicons in metagenomic studies. PLoS ONE 4: e7401

Editorial responsibility: Lisandro Benedetti-Cecchi, Pisa, Italy
Ward JR, Lafferty KD (2004) The elusive baseline of marine disease: Are diseases in ocean ecosystems increasing? PLoS Biol 2:e120

Wardlaw AC, Unkles SE (1978) Bactericidal activity of coelomic fluid from the sea urchin Echinus esculentus. J Invertebr Pathol 32:25-34

Submitted: December 27, 2013; Accepted: April 18, 2014 Proofs received from author(s): May 25, 2014 